Indonesian Science Education Research

(ISER)

Available online https://jurnal.unimed.ac.id/2012/index.php/iser

ISSN Online: 2715-4653

\title{
POSTER UTILIZATION AS A PREVENTION OF DRUG ABUSE IN ADOLESCENTS THROUGH SOCIAL MEDIA
}

\author{
${ }^{1}$ Erpida Ompusungu and Nopita Sitompul \\ ${ }^{1}$ Department of Science Education,Universitas Negeri Medan \\ erpida23@gmail.com
}

Accepted: December $5^{\text {th }}, 2020$. Published: December $31^{\text {th }}, 2020$

\begin{abstract}
Drug trafficking is one of the problems that still occurs in Indonesia and is now a serious problem, especially for adolescents or the younger generation. Adolescents are of productive age who really need special attention, where the level of self-search tends to be unstable and the mindset is instant. Therefore there is anxiety among the community including parents about the behavior of adolescents who are still unable to control themselves in things that are dangerous and destructive to themselves and tend to lead to acts of violating norms or legal rules. So there is a need for efforts to prevent abuse. drugs. One of the triggers for the increasing level of drug abuse is the lack of socialization to the public which results in minimal information about the dangers of narcotics abuse. The purpose of this study was to determine the function of posters on social media in making it easier for the public to obtain information regarding the dangers of narcotics abuse. The instrument used was a poster design uploaded on social media. The method used in data collection is primary data which is obtained directly through comments and suggestions from followers. The results obtained are the easier it is for the public to obtain information about the dangers of drugs as a solution in preventing drug abuse. It is hoped that the use of posters on Instagram social media can become a media of information about the dangers of drug abuse.
\end{abstract}

Keywords: Posters, social media, the dangers of drug abuse 


\section{Introduction}

Narkoba stands for narcotics, drugs or dangerous substances. Another term introduced by the Ministry of Health of the Republic of Indonesia is Napza, which stands for narcotics, psychotropic substances and addictive substances (Dewi, 2019). Drugs are substances / drugs made from natural, synthetic or semisynthetic ingredients that can cause decreased awareness, hallucinations and stimulation effects. Drugs are a problem that is still a lot in Indonesia because of their abuse. Drug abuse is the use of one or several types of drugs regularly or regularly outside of medical indications, causing physical, psychological and social health problems (Azmiyati, 2014).

Addressing the problem of drug abuse requires cooperation from various parties, such as the government and society. There are five ways to tackle drug abuse, namely: promotive, preventive, curative, rehabilitative, and repressive (Hanifah 2011)

Drug abuse in Indonesia has reached a very alarming level, the facts in the field show that around $50 \%$ of LAPAS (Penitentiary) occupants are caused by drug cases (Eleanora, 2011). Use of drugs outside medical indications or without a doctor's prescription, and their careless use can cause abnormalities and cause obstacles in activities (Sadikin, 2018).

Drug abuse can have an impact on other crimes, such as theft, extortion, fraud, robbery, molestation and free sex. Aceh is a city that has cases of increasingly serious drug abuse, has penetrated the entire region of Aceh and is targeting various levels of society without exception (Ismiati, 2018)

Drug abuse is usually based on several things that cause a person to become a user. In general, drug users are grouped into two major sections. First, the causes originating from individual factors such as knowledge, attitude, personality, gender, age, pleasure drive, curiosity, and to solve the problem at hand. Whereas the second second comes from the environment such as work, family disharmony, socio-economic class, and group pressure (Badri, 2013).

Substance dependence is a result of severe drug abuse, it is considered a disease. Addiction, such as the inability to control oneself or stop using substances, can cause enormous physical harm if stopped and harm the family and cause social impacts (Sholihah, 2013).

The causes of drug abuse are divided into two factors: (1) Internal factors, namely factors that come from within the individual such as personality, anxiety, and depression as well as lack of religiosity. Most drug abuse begins or occurs in adolescence, because adolescents who are undergoing rapid biological, psychological and social changes are individuals who are susceptible to abusing these illegal drugs. Children or adolescents with these characteristics are at greater risk of becoming drug abusers. (2) External factors, namely factors originating from outside the individual such as the presence of substances, family conditions, weak laws and environmental influences. The factors above do not always make a person abuse drugs later, but the more factors above, the more likely a person becomes a drug abuse. Individual factors, family environmental factors and peers / associations do not always have the same role in causing someone to abuse drugs. Because social factors can also make a child who comes from a harmonious and quite comminative family become a drug abuser.

Drug use can have negative effects that cause mental and behavioral disorders, resulting in disruption of the neurotransmitter system in the central nervous system in the brain. Various attempts to overcome the development of drug addicts have been made, but are collided with the weakness of the law. Some evidence of the weakness of the law against drugs is that the punishment for traffickers and addicts is very light.

Drug crime is a very dangerous crime, damaging the young generation and the nation's future as well as the character and physique of its users. This crime can also be linked to a number of other crimes, such as robbery, theft, money laundering and terrorism. Therefore, the consequences of drug abuse are not only bad for the users themselves but also directly or indirectly 
will affect the family, community, and state environment (Hikmawati, 2011).

The increasing distribution and abuse of drugs in the community is caused by the lack of information obtained by the public regarding the dangers of drug abuse and the negative effects that drugs can cause. One way that can be done in disseminating information in the community is by utilizing social media which is popular among the community.

Media in delivering information that can be used is by implementing posters on social media. Poster is a graphic design in which there are pictures and words, which contain information. Posters are looking for the attention of many people, posters can also be a means to promote products, services, activities, about education and others. Social media is an online media used for each other where users can easily participate, interact and share in a virtual world without being limited by time and space. Using posters through social media can be used to convey information about drug abuse prevention.

To make an effective communication strategy, there are four stages that must be passed, namely:

1. Knowing consumers, in the communication process both consumers and communicators have the same interest. Consumers can understand the messages conveyed by communicators

2. Composing a message, namely determining the theme and material. The composition of the message must be attractive, can satisfy the needs of the message conveyed, and include the needs of the communicant,

3. Establishing methods, methods that can be taken by the communicator include: (a) repeating the message (b) fulfilling the values and the community group gradually changes it in the desired direction. (c) influencing the audience by providing information which means conveying something as it is. (d) influence in a persuasive way and can be influenced unconsciously by easy situations by suggestion. (e) influencing the audience from an

educational statement (f)

influencing the audience in a coercive way, usually manifested in the form of rules,

4. The use of media, as a channeling tool in order to gain influence in society, namely social media (Arifin, 1994).

Based on the description above, the purpose of this study is to determine the function of posters on social media in making it easier for the public to obtain information related to drug abuse prevention.

\section{Research Method}

This research was a limited research and development research. This research was conducted limited to validation by asking for the opinion of followers on social media. Data collection is done by uploading posters on social media. The sample in this study is the community or followers of the social media. Data obtained from primary data obtained directly through comments and suggestions from the public. The instruments used in this study were posters, and social media, namely Facebook, WhatsApp and Instagram.

\section{Result and Discussion}

\section{Result}

Designing the Concept of Drug Abuse Prevention Efforts

Researchers discuss with lecturers about the design of socialization of efforts to prevent drug abuse through posters that will be uploaded on social media, then researchers look for interesting media references and are able to increase public understanding of drug abuse prevention efforts, namely looking for the images needed to design posters so that they are attractive. the reader's attention. The images you are looking for must match the topic you want to convey on the poster.

Designing Drug Abuse Prevention Effort Poster Designs

After collecting and studying the images needed to make a poster, then design or make an interesting poster design. 
Researchers designed a poster design using the Canva application. that must be considered in making posters are as follows:

1. Using attractive images and in accordance with the message you want to convey,

2. Use language and sentences that are easy to understand and not complicated,

3. Use short, concise and clear sentences,

4. Pay attention to the size of the writing, that is, neither too big nor too small,

5. Look back at the poster that has been designed.

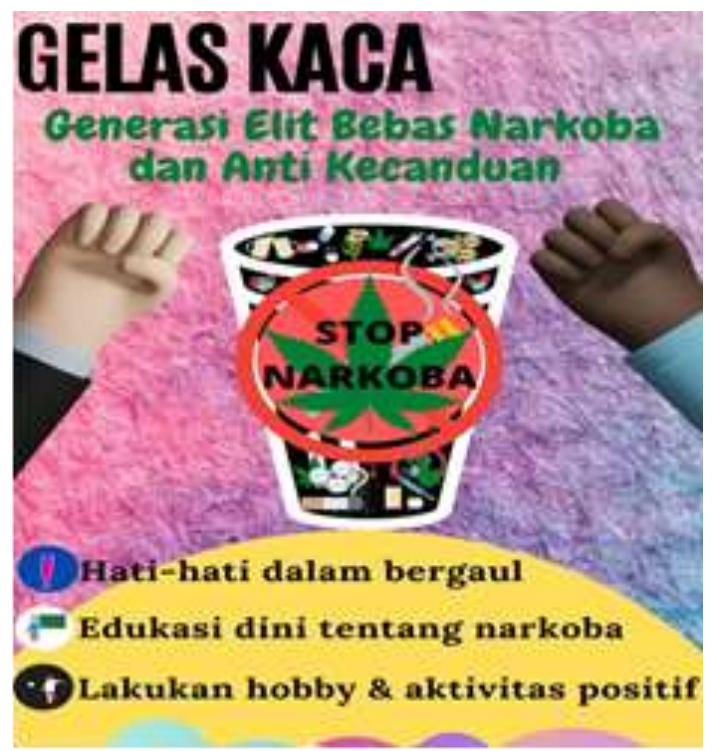

Figure 1. poster design results

An interestingly designed poster, then the poster is uploaded on social media, namely Facebook, Whats App and Instagram. To be able to fully socialize posters to the public, we must choose the right time to upload posters and provide interesting captions so that the posters are seen by many social media users. Posters are uploaded by adding a caption to invite the public to provide comments and suggestions as well as constructive criticism towards improving the poster. After the posters are uploaded, the researcher records and discusses the results of comments and suggestions given by social media users. Then the researcher evaluates and makes improvements to the posters that have been made.

\section{Conclusion}

Poster is a graphic design in which there are pictures and words, the contents of which contain information. Posters are to seek the attention of many people, posters can also be a means to promote products, services, activities, about education and others. Social media is an online media used for each other where users can easily participate, interact and share in a virtual world without being limited by time and space. The social media used to disseminate drug abuse prevention efforts are posters through social media, namely Facebook, WhatsApp and Instagram. Social media is effectively used as a medium of information because social media is currently very popular and widely used by the general public from all walks of life, both in terms of age and profession.

Based on the discussion of the research results it is suggested that further researchers should improve the design, so that the message to be conveyed can be understood by the person who saw the poster.

\section{Reference}

Arifin, A. (1994). Strategi Komunikasi. Bandung: CV. Amrico.

Azmiyati, SR (2014). Gambaran penggunaan NAPZA pada anak jalanan di Kota Semarang.

Badri M. Implementasi Undang-Undang No. 35 Tahun 2009 tentang Narkotika dalam Pelaksanaan Wajib Lapor Bagi Pecandu Narkotika. Jurnal Ilmiah Universitas Batanghari Jambi. 13 (3): 7-12.

Dewi, W. P. (2019). Penjatuhan Pidana Penjara atas Tindak Pidana Narkotika oleh Hakim di Bawah Ketentuan Minimum Ditinjau dari Undang-Undang Nomor 35 Tahun 2009 Tentang Narkotika. Jurnal Hukum Magnum Opus. 2(1).

Eleanora, F. N. (2011). Bahaya Penyalahgunaan Narkoba serta Usaha Pencegahan dan Penanggulangannya (Suatu Tinjauan Teoritis). Jurnal Hukum. 25(1).

Hikmawati, p. (2011). Analisis Terhadap Sanksi Pidana Bagi Pengguna Narkotika. Negara Hukum. 2(2). 329-350.

Ismiati. (2018). Strategi Badan Narkotika 
Nasional Kabupaten (BNNK) Aceh Selatan dalam Upaya Pencegahan dan Penanganan Narkoba. Jurnal AlBayan. 24(2).

Sadikin, A., Nurlinda. (2018). Penyalahgunaan Narkoba dan Psikotropika Di Kalangan Remaja.
Jurnal Ushuluddin Adab dan Dakwah. 1(1).

Sholihah, Q. (2013). Efektivitas Program P4GN terhadap Pencegahan Penyalahgunaan Napza. Jurnal Kesehatan Masyarakat. 9(1). 